\title{
INFLUENCE OF THE CONGRUENCE OF PILOT HOLE TAPPING ON THE ANCHORAGE OF THE PEDICLE SCREW
}

\author{
INFLUÊNCIA DA CONGRUÊNCIA DO MACHEAMENTO DO ORIFÍCIO PILOTO NA \\ ANCORAGEM DO PARAFUSO PEDICULAR
}

\section{INFLUENCIA DE LA CONGRUENCIA DEL TALADRAMIENTO DEL ORIFICIO PILOTO EN EL ANCLAJE DEL TORNILLO PEDICULAR}

\author{
Rodrigo Barra Calado Fleury, ${ }^{1}$ Antônio Carlos Shimano, ${ }^{1}$ Thiago Dantas Matos, ${ }^{1}$ Kelsen de Oliveira Teixeira, ${ }^{1}$ Valéria Romero, ${ }^{2}$ Helton Luiz Aparecido Defino ${ }^{1}$ \\ 1. Universidade de São Paulo, Faculdade de Medicina de Ribeirão Preto, Department of Biomechanics, Medicine and Rehabilitation of the Locomotor Apparatus, Ribeirão Preto, SP, Brazil.
} 2. Universidade Estadual de Campinas, Faculdade de Ciências Médicas, Department of Clinical Medicine, Campinas, SP, Brazil.

\begin{abstract}
Objectives: To observe the influence of the congruence of the tapping of the pilot hole on the anchorage of the pedicle screws. Methods: 5.5 and $6.5 \mathrm{~mm}$ screws from two vertebral fixation systems (Pedicol and Safe) were inserted into polyurethane blocks. Experimental groups were formed according to the pilot hole preparation: A- drilling with a $2.7 \mathrm{~mm}$ drill bit, B- Tapping of the pilot hole with a tap of lesser diameter than the diameter of the screw with a congruent thread design, C- Tapping of the pilot hole with a tap of lesser diameter than the diameter of the screw and an incongruous thread design. The polyurethane blocks with the screws were subjected to a tensile strength test to evaluate the pullout resistance of the screws. Results: Using congruent pilot hole tapping of a lesser diameter and congruent thread design increased the pullout resistance of the rough-surface screws (Safe). The screws with a smooth surface (Pedicol) presented greater pullout resistance with tapping of a lesser diameter and incongruous thread design. Conclusions: The congruence of the tap used to prepare the pilot hole increased the pullout resistance of the rough-surfaced screws. Level of Evidence III; Therapeutic Study.
\end{abstract}

Keywords: Spine; Bone Screws; Biomechanical Phenomena.

\section{RESUMO}

Objetivos: Observar a influência da congruência do macheamento do orifício piloto na ancoragem dos parafusos pediculares. Métodos: Parafusos de 5,5 e 6,5 mm, pertencentes a dois sistemas de fixação vertebral (Pedicol e Safe), foram introduzidos em blocos de poliuretano. Os grupos experimentais foram formados de acordo com o preparo do orifício piloto: A - perfuração com broca de 2,7 $\mathrm{mm}, \mathrm{B}$ - macheamento do orifício piloto com macho de diâmetro inferior ao diâmetro do parafuso e desenho de rosca congruente, C - macheamento do orifício piloto com macho de diâmetro inferior ao diâmetro do parafuso e desenho de rosca incongruente. Os blocos de poliuretano com os parafusos foram submetidos a ensaio de resistência à tração para avaliar a resistência dos parafusos ao arrancamento. Resultados: A utilização do macheamento do orifício piloto de menor tamanho e congruente aumentou a resistência ao arrancamento dos parafusos de superfície rugosa (Safe). Os parafusos de superfície lisa (Pedicol) apresentaram maior resistência ao arrancamento com a utilização do macheamento com menor diâmetro e incongruente. Conclusões: A congruência do macho utilizado para o preparo do orifício piloto aumentou a resistência ao arrancamento nos parafusos de superfície rugosa. Nível de Evidência III; Estudo terapêutico.

Descritores: Coluna Vertebral; Parafusos Ósseos; Fenômenos Biomecânicos.

\section{RESUMEN}

Objetivos: Observar la influencia de la congruencia del taladramiento del orificio piloto en el anclaje de los tornillos pediculares. Métodos: Fueron introducidos tornillos de 5,5 y 6,5 mm, pertenecientes a dos sistemas de fijación vertebral (Pedicol y Safe) en bloques de poliuretano. Los grupos experimentales fueron formados de acuerdo con la preparación del orificio piloto: A- perforación con broca de 2,7 mm, B-taladramiento del orificio piloto con mecha de diámetro inferior al diámetro del tornillo y diseño de rosca congruente, C-taladramiento del orificio piloto con mecha de diámetro inferior al diámetro del tornillo y diseño de rosca incongruente. Los bloques de poliuretano con los tornillos fueron sometidos a ensayo de resistencia a la tracción para evaluar la resistencia de los tornillos al arrancamiento. Resultados: El uso del taladramiento del orificio piloto de menor tamaño y congruente aumentó la resistencia al arrancamiento de los tornillos de superficie rugosa (Safe). Los tornillos de superficie lisa (Pedicol) presentaron mayor resistencia al arrancamiento con el uso del taladramiento con menor diámetro e incongruente. Conclusiones: La congruencia de la mecha utilizada para la preparación del orificio piloto aumentó la resistencia al arrancamiento en los tornillos de superficie rugosa. Nivel de Evidencia III; Estudio terapéutico.

Descriptores: Columna Vertebral; Tornillos Óseos; Fenómenos Biomecánicos. 


\section{INTRODUCTION}

Spinal fixation systems that use the vertebral pedicle to anchor implants have been universally used due to the biomechanical advantages of these fixation systems. ${ }^{1}$

The biomechanical properties of pedicular fixation systems are directly related to the anchoring of the screws in the vertebral pedicles. ${ }^{2}$ Anchoring of the screws in the vertebral pedicles depends on bone density, the material and design of the implant and the preparation of the pilot hole. ${ }^{3}$

In the preparation of the pilot hole, the diameter of the perforation in relation to the screw dimensions and the preparation method influence the anchorage of the implants. ${ }^{4,5}$ The diameter of the pilot hole should be smaller than the external diameter of the implant and of the tapping of the pilot hole. ${ }^{6}$ Tapping the pilot hole with a diameter equal to that of the external diameter of the implant reduces the pullout resistance of the implants and tapping of the pilot hole with a diameter smaller than the external diameter of the screw has been recommended..$^{7-9}$ The thread design of the tap has been indicated as another parameter related to the preparation of the pilot hole that influences implant pullout resistance, and using a tap with a smaller diameter than the implant and with the same thread design has been recommended. ${ }^{6}$

Reporting of the influence of the design and dimensions of the tap thread on the pullout resistance of the implants motivated this study. The objective of the present study was to evaluate the influence of the design and dimensions of the tap threads used to prepare the pilot hole on the pullout resistance of the pedicular fixation system screws.

\section{METHODS}

The experimental model for the study was designed so that screws of the same diameter $(5.5$ and $6.5 \mathrm{~mm}$ ) and with different thread design and dimensions, belonging to two spinal fixation systems (Pedicol and Safe - Víncula, Brazil) were subjected to mechanical pullout resistance trials, following preparation of a pilot hole with tapping of a smaller diameter than the external diameter of the pedicle screw, using taps of the same diameter and different thread designs.

Blocks of polyurethane with a density of 10 PCF or $0.16 \mathrm{~g} / \mathrm{cm}^{3}$ and dimensions of $5 \mathrm{~cm} \times 8 \mathrm{~cm} \times 5 \mathrm{~cm}$ (Nacional Ltda) were used. A pilot hole was drilled in the center of the upper face of each polyurethane block with a $2.7 \mathrm{~mm}$ bit. The screws were inserted into the pilot holes forming three experimental groups: A - without tapping of the pilot hole; $\mathrm{B}$ - with tapping of the pilot hole using a tap of lesser diameter than the external diameter of the screw and with a similar thread design; $\mathrm{C}$ - with tapping of the pilot hole using a tap of lesser diameter than the external diameter of the screw and with a different thread design. (Table 1) The pilot holes were tapped to the same depth as the screw length $(40 \mathrm{~mm})$.

Pedicular fixation system screws (Safe Víncula, Brazil and Pedicol Plus Víncula, Brazil) with external diameters of $5.5 \mathrm{~mm}$ and 6.5 $\mathrm{mm}$ and length of $40 \mathrm{~mm}$ were used, (Table 2) The screws of the

Table 1. Values of the taps used and their respective external diameters and thread pitches.

\begin{tabular}{c|c|c}
\hline Tap & External diameter $(\mathbf{m m})$ & Thread pitch $(\mathbf{m m})$ \\
\hline Pedicol $5.0 \mathrm{~mm}$ & 5.0 & 2.5 \\
\hline Pedicol $6.0 \mathrm{~mm}$ & 6.0 & 2.5 \\
\hline Safe $5.0 \mathrm{~mm}$ & 5.0 & 2.25 \\
\hline Safe $6.0 \mathrm{~mm}$ & 6.0 & 2.25 \\
\hline
\end{tabular}

Table 2. Values of the screws used and their respective external diameters and thread pitches.

\begin{tabular}{c|c|c}
\hline Screw & External diameter $(\mathbf{m m})$ & Thread pitch (mm) \\
\hline Pedicol $5.0 \mathrm{~mm}$ & 5.5 & 2.5 \\
\hline Pedicol $6.0 \mathrm{~mm}$ & 6.5 & 2.5 \\
\hline Safe $5.0 \mathrm{~mm}$ & 5.5 & 2.25 \\
\hline Safe $6.0 \mathrm{~mm}$ & 6.5 & 2.25 \\
\hline
\end{tabular}

Safe Víncula pedicular fixation system have a rough surface and the screws of the Pedicol Plus Víncula pedicular fixation system have a smooth surface. The screws of both systems are made of F-136 titanium and a conical internal diameter.

Each experimental group was formed according to the type of screw used (Safe or Pedicol Plus), the diameter of the screw (5.5 and $6.5 \mathrm{~mm}$ ) and the mode of pilot hole preparation (A- without tapping of the pilot hole; $\mathrm{B}$ - with tapping of the pilot hole using a tap of lesser diameter than the external diameter of the screw and with a similar thread design; $\mathrm{C}$ - with tapping of the pilot hole using a tap of lesser diameter than the external diameter of the screw and with a different thread design). Each experimental group consisted of five polyurethane blocks.

Screw pullout resistance was evaluated using the EMIC $₫$ universal testing machine (DL 10000; EMIC, São José dos Pinhais, PR, Brazil). Figure $1 \mathrm{~A}$ rod was connected to the head of the screw and the pullout force applied vertically. The pullout resistance was applied at a velocity of $2.0 \mathrm{~mm} / \mathrm{min}$ until the screw was pulled out of the polyurethane block.

\section{Statistical Analysis}

Statistical analysis was performed using a parametric approach, in which the Student's t-test was used to compare the means of all groups. Prior to the t-test, we verified that the data followed all application restrictions, normality (assessed by means of the Shapiro-Wilk test) and equal variances (by means of the $F$ test).

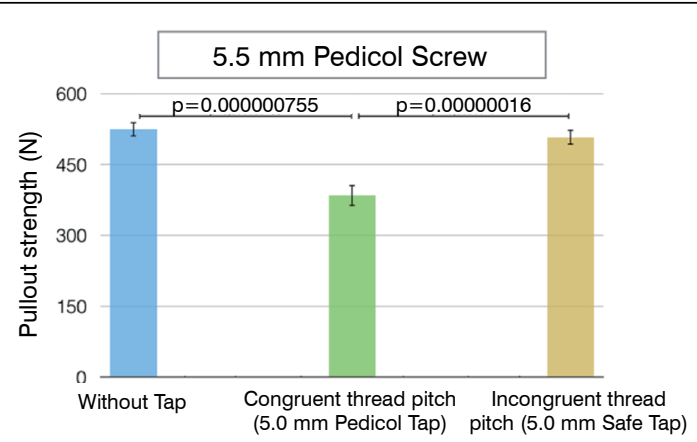

Figure 1. Graph showing the pullout strength of the Pedicol $5.5 \mathrm{~mm}$ screws for the different pilot hole preparation modalities.

\section{RESULTS}

The pullout resistance trial results are illustrated in Table 3 and Figures 1 to 4 .

The $5.5 \mathrm{~mm}$ and $6.5 \mathrm{~mm}$ smooth screws (Pedicol) had greater pullout resistance when the pilot hole was tapped with a tap of smaller diameter and a different thread pitch than the screw. (Figures 1 and 2) In this screw modality, the use of tapping with a smaller diameter and a different thread pitch than the screw increased the pullout resistance of the screws. (Figures 1 and 2) Insertion of the screw without pilot hole tapping had greater pullout resistance than the group in which the tapping was performed with a smaller diameter tap than and a thread pitch similar to the screw. (Figures 1 and 2)

The rough screws (Safe) of $5.5 \mathrm{~mm}$ and $6.5 \mathrm{~mm}$ had greater pullout resistance when tapping of the pilot hole was performed with a tap of lesser diameter than and thread pitch similar to the screw. (Figure 3 and 4) In this screw modality, use of a tap of lesser diameter than and thread pitch similar to the screw increased the pullout resistance of the screws. (Figures 3 and 4) Not tapping the pilot hole increased screw pullout resistance between the different pilot hole preparation modalities only for the $6.5 \mathrm{~mm}$ screws. (Figures 3 and 4) For the $6.5 \mathrm{~mm}$ screws, the non-tapping of the pilot hole increased the pullout resistance as compared to the other pilot hole preparation modalities. For the $5.5 \mathrm{~mm}$ screws, non-tapping of the pilot holes increased the resistance only in relation to the group 
in which pilot hole preparation was performed with a tap of smaller diameter and different thread pitch than the screw. (Figures 3 and 4)

The comparison between the pullout strength values of the different experimental groups is illustrated in Tables 3 and 4.

Table 3. Mean and standard deviation values for the pullout force of the different experimental groups.

\begin{tabular}{c|c|c}
\hline Screw (mm) / Tap model (mm) & Standard deviation (n) & Mean (n) \\
\hline Pedicol 5.5 / Tap 5.0 Pedicol & 22.19 & 384.38 \\
\hline Pedicol 5.5 / Tap 5.0 Safe & 15.34 & 507.28 \\
\hline Pedicol 5.5 / Without tapping & 14.86 & 524.36 \\
\hline Pedicol 6.5 / Tap 6.0 Pedicol & 45.40 & 451.64 \\
\hline Pedicol 6.5 / Tap 6.0 Safe & 12.35 & 568.25 \\
\hline Pedicol 6.5 / Without tapping & 29.39 & 622.72 \\
\hline Safe 5.5 / Tap 5.0 Safe & 46.80 & 476.80 \\
\hline Safe 5.5 / Tap 5.0 Pedicol & 34.82 & 365.17 \\
\hline Safe 5.5 / Without tapping & 48.55 & 536.35 \\
\hline Safe 6.5 / Tap 6.0 Safe & 49.86 & 518.33 \\
\hline Safe 6.5 / Tap 6.0 Pedicol & 26.52 & 357.10 \\
\hline Safe 6.5 / Without tapping & 17.31 & 599.43 \\
\hline \multicolumn{2}{|l}{}
\end{tabular}

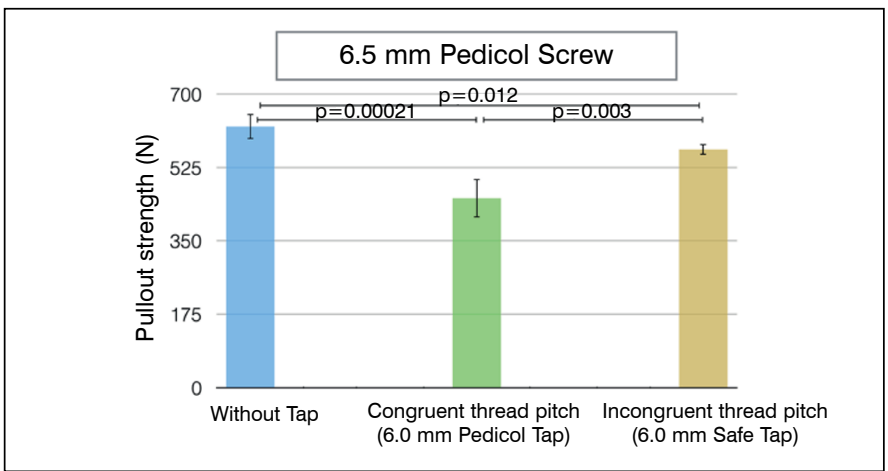

Figure 2. Graph showing the pullout strength of the Pedicol $6.5 \mathrm{~mm}$ screws for the different pilot hole preparation modalities.

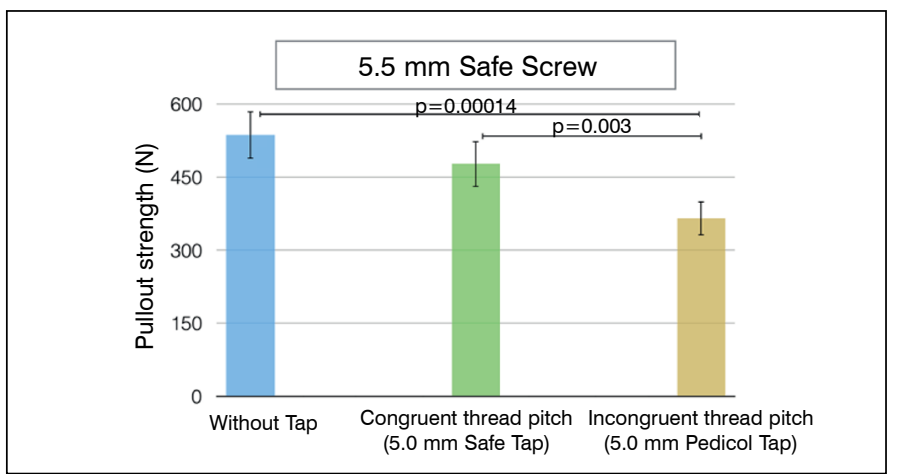

Figure 3. Graph showing the pullout strength of the Safe $5.5 \mathrm{~mm}$ screws for the different pilot hole preparation modalities.

\section{DISCUSSION}

The thread design of the tap used to prepare the pilot hole influenced the pullout resistance of the spinal fixation system screws used in this study. In the rough-surfaced screws (Safe) tap congruence increased pedicle screw pullout resistance. In the smooth-surfaced screws (Pedicol) pullout resistance was observed with the use of incongruent tapping.

Pedicle screws have been widely used in spinal fixation systems and their insertion into the vertical pedicle has been carried out by drilling a pilot hole, followed by tapping and insertion of the screws into the vertebral pedicle. These technical steps were influenced by the technique of osteosynthesis of long bones, in which the pilot

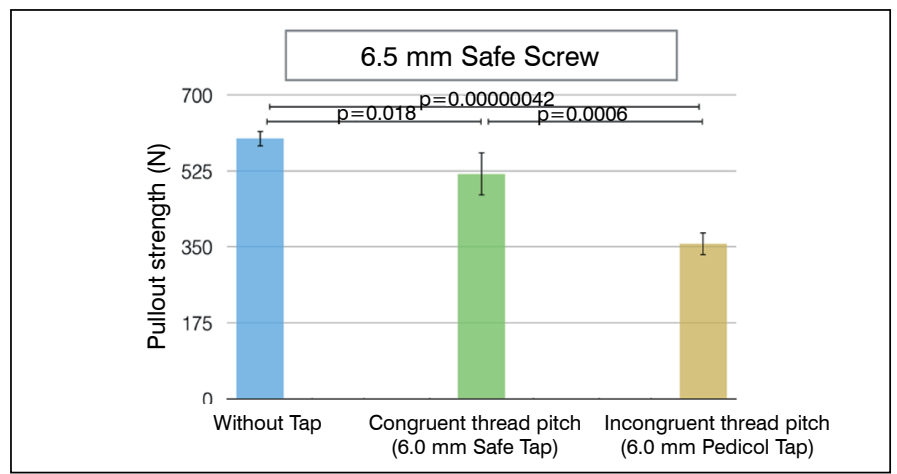

Figure 4. Graph showing the pullout strength of the Safe $6.5 \mathrm{~mm}$ screws for the different pilot hole preparation modalities.

Table 4. Results of the comparison of pullout strength values between the experimental groups (Student's t-test $-p<0.05$ )

\begin{tabular}{|c|c|}
\hline Comparisons & t-test \\
\hline Pedicol $5.5 \mathrm{~mm}$ 5P vs. Pedicol $5.5 \mathrm{~mm} 5 \mathrm{~S}$ & 0.0000016 \\
\hline Pedicol $5.5 \mathrm{~mm}$ Without tapping vs. Pedicol $5.5 \mathrm{~mm} 5 \mathrm{P}$ & 0.000000755 \\
\hline Pedicol $5.5 \mathrm{~mm}$ Without tapping vs. Pedicol $5.5 \mathrm{~mm}$ 5Safe & 0.26 \\
\hline Pedicol 6.5 mm 6P vs. Pedicol 6.5 mm 6Safe & 0.003 \\
\hline Pedicol $6.5 \mathrm{~mm}$ Without tapping vs. Pedicol $6.5 \mathrm{~mm} 6 \mathrm{P}$ & 0.00021 \\
\hline Pedicol $6.5 \mathrm{~mm}$ Without tapping vs. Pedicol $6.5 \mathrm{~mm}$ 6Safe & 0.012 \\
\hline Safe $5.5 \mathrm{~mm} 5 \mathrm{~S}$ vs. Safe $5.5 \mathrm{~mm} 5 \mathrm{P}$ & 0.003 \\
\hline Safe $5.5 \mathrm{~mm}$ Without tapping vs. Safe $5.5 \mathrm{~mm} 5 \mathrm{P}$ & 0.00014 \\
\hline Safe $5.5 \mathrm{~mm}$ Without tapping vs. Safe $5.5 \mathrm{~mm} 5 \mathrm{~S}$ & 0.08 \\
\hline Safe $6.5 \mathrm{~mm} 6 \mathrm{~S}$ vs. Safe $6.5 \mathrm{~mm} 6 \mathrm{P}$ & 0.0006 \\
\hline Safe $6.5 \mathrm{~mm}$ Without tapping vs. Safe $6.5 \mathrm{~mm} 6 \mathrm{P}$ & 0.00000042 \\
\hline Safe $6.5 \mathrm{~mm}$ Without tapping vs. Safe $6.5 \mathrm{~mm} 6 \mathrm{~S}$ & 0.018 \\
\hline
\end{tabular}

hole was prepared for the precise insertion of the screws into the cortical bone. Tapping of the pilot hole allowed the configuration of the screw design in the cortical bone and its adaptation, avoiding fractures of the adjacent cortical bone. ${ }^{4}$ Tapping of the cortical bone was performed using the same diameter as the screw. However, in spongy bones and in the spine, tapping of the pilot hole with the same diameter as the screw caused a reduction in the pullout resistance of the implants. ${ }^{8,9}$

Pilot hole tapping with the same diameter as the screws reduces the pullout resistance of the screws and offers no advantages. ${ }^{5}$ The practice of tapping of the spinal fixation system screws has been carried out with a diameter less than the diameter of the pedicle screw and biomechanical studies have demonstrated the biomechanical superiority of tapping the pilot hole with a diameter smaller than the diameter of the pedicle screws. ${ }^{6}$ They observed that a tap with a diameter $1 \mathrm{~mm}$ smaller than the screw increased the pullout resistance of the pedicle screws. ${ }^{7}$ Unlike tapping of the cortical bones, tapping of the pedicle screw pilot hole with a diameter smaller than the diameter of the screws increases pedicle screw pullout resistance and has been used in spinal fixations systems. ${ }^{10}$

The tapping of pedicle screw pilot holes has been very frequently used for the placement of pedicle screws, considering the biomechanical reasons mentioned and also as a safety measure to verify the integrity of the vertebral pedicle walls prior to the introduction of the pedicle screws, in addition to allowing the screw to be inserted with less resistance, facilitating screw insertion. The use of a pilot hole of lesser diameter and the abolition of tapping increased the pullout resistance of the screws. ${ }^{6}$ This fact was observed in all the experimental groups in our study. However, during the surgical implantation of the pedicle screws, the abolition of tapping prevented verification of the integrity of the pedicle walls prior to the insertion of the implants.

Tapping of the pilot hole with a tap of lesser diameter than the screw is based on biomechanical studies performed ${ }^{7}$ and the importance of the thread pitch design of the tap was reported by 
Bohl et al., In mechanical trials, these authors observed that using incongruent taps, that is, with a thread pitch different than the pedicle screw, reduces the pullout resistance of the implants. ${ }^{6}$

In our study, the influence of the incongruence of the tap thread pitch in the preparation of the pilot hole was partially observed. Only one screw modality (Safe), which has a rough surface, presented the pattern described by Bohl et al., in which the incongruence of the tapping caused screw pullout resistance. In the smooth-surfaced screws (Pedicol) the effect observed in our study was contrary to that described by Bohl et al., greater pullout resistance of the implants having been observed with the use of an incongruent tap.

The experimental model used to evaluate the hypothesis that the congruence of the pilot hole tap influences pedicle screw pullout resistance should take into account that polyurethane is homogeneous in nature and similar to spongy vertebral bone, but in reality it is a synthetic material with properties different than those of the vertebrae. However, this model has been widely used and reported as clinically valid. ${ }^{11,12}$ In the analysis of the model, the fact that pedicular fixation system screws are mainly submitted to cyclic loads, in contrast to the pedicle screw pullout resistance used in the study, should also be considered. These considerations do not invalidate the model used or the results, but serve to assist in the critical analysis of the results.

The pullout resistance of pedicle screws is very important to the mechanical stability of pedicular fixation systems and is dependent on the implants, the bone density and the preparation of the pilot hole. ${ }^{4,5}$ The preparation of the pilot hole is the only parameter that is dependent on the surgeon during the surgical procedure and can alter the final outcome of the treatment performed.

The influence of the congruence of pilot hole tapping and the pullout resistance of the implants may be only one of the factors that make up the constellation of elements that influence the stability of implant anchorage. In our study, this influence can only be partially observed in the results of the rough-surfaced screws, which did not fully corroborate other studies, ${ }^{6}$ reinforcing the need for further study in this area to confirm the relevance of the congruence of pilot hole tapping to pedicle screw anchorage.

\section{CONCLUSION}

The congruence of pilot hole tapping influenced the pullout resistance of the pedicle screws with a rough surface. In the pedicle screws with a smooth surface the use of incongruent taps increased the pullout resistance of the implants.

All authors declare no potential conflict of interest related to this article.

CONTRIBUTION OF THE AUTHORS: Each author made significant individual contributions to this manuscript. RBCF: substantial contributions to the concept and design of the study, acquisition and interpretation of data and final approval of the version to be published. KT: contribution to data collection and analysis. TDM: contribution to data collection and analysis. ACS: substantial contributions to data collection. HD: substantial contributions to the concept and design of the study, analysis and interpretation of the data and final approval of the version to be published. VR: review of the important intellectual content.

\section{REFERENCES}

1. Tsai WC, Chen PQ, Lu TW, Wu SS, Shih KS, Lin SC. Comparison and prediction of pullout strength of conical and cylindrical pedicle screws within synthetic bone. BMC Musculoskelet Disord. 2009;10:44.

2. Weinstein JN, Rydevik BL, Rauschning W. Anatomic and technical considerations of pedicle screw fixation. Clin Orthop Relat Res. 1992;(284):34-46.

3. Koranyi E, Bowman CE, Knecht CD, Janssen M. Holding power of orthopedic screws in bone. Clin Orthop Relat Res. 1970;72:283-6.

4. Oktenoğlu BT, Ferrara LA, Andalkar N, Ozer AF, Sarioğlu AC, Benzel EC. Effects of hole preparation on screw pullout resistance and insertional torque: a biomechanical study. $J$ Neurosurg. 2001:94(1 Suppl):91-6.

5. Zdeblick TA, Kunz DN, Cooke ME, McCabe R. Pedicle screw pullout strength. Correlation with insertional torque. Spine (Phila Pa 1976). 1993;18(12):1673-6.

6. Bohl DD, Basques BA, Golinvaux NS, Toy JO, Matheis EA, Bucklen BS, et al. Undertapping of Lumbar Pedicle Screws Can Result in Tapping With a Pitch That Differs From That of the Screw, Which Decreases Screw Pullout Force. Spine (Phila Pa 1976). 2015;40(12):E729-34
7. Chatzistergos PE, Sapkas G, Kourkoulis SK. The influence of the insertion technique on the pullout force of pedicle screws: an experimental study. Spine (Phila Pa 1976). 2010;35(9):E332-7.

8. Phan K, Hogan J, Maharaj M, Mobbs RJ. Cortical Bone Trajectory for Lumbar Pedicle Screw Placement: A Review of Published Reports. Orthop Surg. 2015;7(3):213-21.

9. Derincek A, Wu C, Mehbod A, Transfeldt EE. Biomechanical comparison of anatomic trajectory pedicle screw versus injectable calcium sulfate graft-augmented pedicle screw for salvage in cadaveric thoracic bone. J Spinal Disord Tech. 2006;19(4):286-91.

10. Kuklo TR, Lehman RA. Effect of various tapping diameters on insertion of thoracic pedicle screws: a biomechanical analysis. Spine (Phila Pa 1976). 2003;28(18):2066-71.

11. Conrad BP, Cordista AG, Horodyski M, Rechtine GR. Biomechanical evaluation of the pullout strength of cervical screws. J Spinal Disord Tech. 2005;18(6):506-10.

12. Brown GA, McCarthy T, Bourgeault CA, Callahan DJ. Mechanical performance of standard and cannulated 4.0-mm cancellous bone screws. J Orthop Res. 2000;18(2):307-12 